\title{
Employees and Managers Attitude towards Privatization Programs: Evidence from an Emerging Economy
}

\author{
Abdullah Al-Mutairi ${ }^{1}$, Kamal Naser ${ }^{2}$ \& Fatema Fayez ${ }^{1}$ \\ ${ }^{1}$ Arab Open University- Kuwait branch, Kuwait \\ ${ }^{2}$ Financial and Economic Advisor, Kuwait Fund, Kuwait \\ Correspondence: Abdullah AL-Mutairi, Department of Business Administration, Arab Open University- Kuwait \\ branch, Kuwait. E-mail: Drabdulla2011@hotmail.com
}

Received: September 22, 2014

doi:10.5539/ijef.v6n12p95

\author{
Accepted: October 16, $2014 \quad$ Online Published: November 25, 2014 \\ URL: http://dx.doi.org/10.5539/ijef.v6n12p95
}

\begin{abstract}
This study is set out to explore employees and management attitude towards privatization in Kuwait. To a chive this objective, a questionnaire has been distributed to employees and managers of 21 privatized companies and they were requested to state to what extent they agree or disagree with different aspects of privatization. The results of analyzing their responses revealed that a successful privatization program in Kuwait should be restricted to outsourcing, deregulation and joint venture partnerships forms of privatization. The analysis also showed that privatization would confront difficulties due to the absence of competition and profit incentives in the public sector enterprises, some projects entail social responsibility that cannot be attained by the private sector, privatization might result in employees' lay-off and fear of extensive government regulation. The results of the analysis further affirmed that privatization would be restricted to light and moderate industries, communication and luxury goods and services and the government should continue being responsible for some strategic enterprises such as education, electricity, health and water. Finally, the results of the analysis illustrated that effective privatization can result in improvement in the quality of goods and services, development in foreign economic relations with Kuwait, improvement in investment climate in Kuwait, increase in competition and ultimately stimulate economic growth.
\end{abstract}

Keywords: privatization, public sector, firm performance, employee job satisfaction, Kuwait

\section{Introduction}

Several studies have been undertaken to investigate privatization. These studies looked at privatization through three main dimensions: The first dimension focused on the impact of Initial Public Offerings (IPOs) on stock returns (see for example: Kiymaz, 2000; Kim et al., 2002; Helwege \& Liang, 2004; Peter, 2007). The second dimension made comparison between the firm performance before and after the privatization (See for example: Peter et al., 2010; Tsamenyi et al., 2010; Al Qudah, 2011). The third dimension considered employees perception about privatization programs (see for example: Struwig \& Scheers, 2004; Shahzad, 2005; Momen, 2007; Islam \& Farazmand, 2008; Ram, 2012; Jresat, 2012; Sarmah, 2013; Kousadikar \& Singh, 2013). The focus of the current study will be on the third dimension since it is more relevant to the privatization program in Kuwait than the other two dimensions. In addition, the first two dimensions involve assessing the aftermath privatization, whereas the third dimension is important to ensure smooth execution of any privatization program in a rich country like Kuwait.

Kuwait is an oil producing country and its public sector offers its employees attractive salaries together with other generous employment benefits and pension. Within this environment, the private sector will find it extremely difficult to compete with the public sector. Consequently, the public sector of Kuwait is becoming the major employer of the national labor force. According to the Public Authority for Civil Information (2013), almost $75 \%$ of the total Kuwait labor force is employed by the public sector.

In addition, Kuwait is the only Arab Gulf country that has a freely elected Parliament. In a small society like Kuwait, the members of Parliament will find it difficult not to support the public sector labor force if they decided to go against any privatization program. Kuwaiti employees are not willing to leave secured, highly paid government jobs for risky and not financially rewarding private sector employment. Within this context, 
exploring employees' perception about the privatization program in Kuwait is of paramount importance, since the success or otherwise of such a program in Kuwait is totally dependent on employees' attitude. More importantly, Kuwait shares many Arab Gulf countries their characteristics in that the public sector is the major employer of their national labor force and offers attractive employment packages, this study will assist them in formulating their privatization programs. Thus, exploring managers and employees' attitude towards privatization in Kuwait is of interest to policymakers, employers and employees. For policymakers, this study is expected to assist in deciding what courses of action to adopt when undergoing any privatization program in order to make the transaction as smooth and effective as possible. For employees who are going to be responsible for undertaking the work in a privatized environment, it is important to hold favorable attitudes towards privatization to ensure a successful program. For employers, it is expected to provide insight about employees in order to satisfy their needs and interests to ensure productivity and efficiency.

This study will further contribute to the existing body of literature about privatization from a unique environment like the Gulf Cooperation Council (GCC) region. With more nation states moving toward privatization, there is a need for more studies concerning how employees perceive changes in employment system since there job satisfaction is highly associated with their productivity.

The remaining of the study is organized as follows: previous studies are reviewed in the following section. While a brief description of the study's methodology is presented in section 3 , the results are discussed in section 4 . The conclusion is offered in the last section.

\section{Previous Related Studies}

Privatization means transferring property or businesses ownership from the public sector to the private sector. Privatization is not a panacea it is rather an engine that leads to an improvement in financial or administrative aspects of the firm (Kousadikar \& Singh, 2013). Akram (1999) stated that privatization is an essential part of the process of transition to a new economic regime that supports economic growth and development in Bangladesh. Akram suggested that the state's privatization policy must prevent direct unproductive profit-seeking activities that hamper economic growth and development. Therefore, a privatization program might be tailored to achieve specific objectives of government's policy (Shehadi, 2002). Kikeri et al. (1994) pointed to two conditions for successful privatization. While the first is related to a country's ability to offer a stable and predictable investment environment, the second is associated with the market ability to offer a competitive environment that ensures efficiency. Similarly, Reid (1994) referred to two conditions to achieve privatization goals. He indicated that first: the state-controlled enterprises should be independent of their supervising bureaucracies before being transferred to the private sector and second the government should possess monitoring capacity to ensure the accomplishment of contractual commitments of the privatized firm. The major assumption of privatization is that private management ensures the shareholders interest by delivering a much better economic performance than do politicians or bureaucrats (Shehadi, 2002). According to Taylor and Warrack (1998) efficiency is a winning driver towards privatization. Selvi and Yilmaz (2010) believe that the main objective of privatization is to not only privatize State-Owned Enterprises (SOE's), but also keep the sustainability of privatized SOE's.

Several studies have been conducted to examine employees attitudes toward privatization program (see for example, Turkey: Keller et al., 1994; Ertuna, 1998; Nichols et al., 1998; Tansel, 2001; Selvi \& Yilmaz, 2010; Chile: Milman, 1996. UK: Eiser et al., 1996; Struwig \& Scheers, 2004. Croatia: Goic, 1999. Bangladesh: Akram, 1999; Shahzad, 2005; Momen, 2007; Islam \& Farazmand, 2008. Sri Lanka: Lalkanthi \& Mahaliyanaarachchi, 2001. China: Dong et al., 2002. France: Durant \& Legge, 2002. Sudan: Musa, 2002. Jordan: Awamleh, 2002; Al-Adaileh, 2004; Ram, 2012; Jresat, 2012. Hong Kong: Shun 2005. Latin America: Carrera et al., 2005. Ecuador: Wated et al., 2008. Indonesia: Yonnedi, 2009. India: Sarmah, 2013; Kousadikar \& Singh, 2013). A brief review of these studies is offered in the following section.

Keller et al. (1994) examined privatization policies in Turkey. They found that privatization can be useful for the Turkish economy if it is accompanied by necessary regulation and competition. They observed that the sale of State Economic Enterprises by blocks will not help in achieving the required objectives. Keller et al. concluded that privatization seems to increase unfairness of income distribution. Ertuna (1998) argued that improving the legal structure and getting the involvement of the parliament are important to the success of the privatization programs. He stated that privatization is more complicated than simple "sale" of government assets. Hence, it is important to consider environment differences across countries and stated objectives of privatization. Ertuna concluded that it is important to rely on success stories rather than relying only on a simple propaganda. Nichols et al. (1998) compared employees' opinions about privatization in Turkey and Britain. They found less hostility to privatization among employees in Turkey than in Britain. Nichols et al. contended that this difference is 
attributed to specific historical and institutional differences between the two countries. Tansel (2001) examined the impact of privatization on dismissed employees in Turkey. He found that employees felt that they have not been fully compensated for what they had lost by the severance pay they received.

Milman (1996) surveyed attitudes towards debt-equity-swaps and privatization of SOEs in Chile. He found privatizing SOEs is likely to improve economic development particularly in countries where SOEs participate in economic activities. Milman indicated that the success of a privatization program is dependent on specific measures to be taken by government such as clear, consistent and reliable regulatory framework for privatized firms combined with macro-economic policies that match the privatization program.

Eiser et al. (1996) explored individuals' attitudes toward the impending privatization of the UK electricity supply and water industries. The researchers found that respondents did not consider privatization to be corrective for poor previous industrial practice rather than it would lead to improvement where an industry was seen as performing well and deterioration where it was seen as performing badly. On the other hand, Struwig and Scheers (2004) examined the impact of privatization on front line employees in a service organization. They found that employees have received better training, appreciated a better system of communication and experienced a higher degree of empowerment.

Goic (1999) studied employees' attitudes towards employee ownership and financial participation in Croatia. He noticed that employees there demonstrated strong eagerness to participate in enterprises ownership not only because of the mere worth of the property and possible financial results but because of the wish to access information, participation in decision making and the safeguard of working place. Goic also found that employees' financial participation is more evident in large enterprises and employees' involvement might be most efficient just through financial participation in ownership and in financial results.

Shahzad (2005) noticed that the performance of privatized enterprises has not improved significantly. However, Momen (2007) found that some privatized enterprises have done well while others have not reached the target of privatization. Consequently, Momen suggested that privatization in Bangladesh needs to focus attention on postprivatization problems faced by enterprises. Islam and Farazmand (2008) used case studies and official interview to examine the effectiveness of privatization programs in Bangladesh. They found that civil servants believe that privatization has a positive influence on economic, social, political and administrative development. Islam and Farazmand, however, observed that privatization has a negative influence on equity, fairness and social justice issues as a result of widening the gap between the poor and rich.

Lalkanthi and Mahaliyanaarachchi (2001) investigated vegetable farmers' attitudes towards the privatization of agricultural extension service. They found that the majority of country vegetable farmers have positive attitudes towards privatization of agricultural extension service. They observed that type of labor, monthly profit, monthly total income and management ability have a direct effect on farmers' attitudes. They concluded that it is feasible to privatize agricultural extension service in the vegetable sector in Sri Lanka.

In China, Dong et al. (2002) found employees with higher levels of education consistently report lower levels of job satisfaction and perceive that they have less participation in firm decision-making. The researchers also found that employees in the non-privatized firms perceive themselves to have a greater voice in enterprise decision-making than non-shareholder employees in privatized firms, they showed greater satisfaction with many job aspects, and express lower exit intentions than employees in privatized firms.

Durant and Legge (2002) noticed that France greater commitment to providing social services for protecting social safety may have eased lower-income persons' concern about the impact of privatization on them. Durant and Legge recommended that policy targeted towards employability rather guaranteed employment could be more profitable.

Musa (2002) noticed that Employee Ownership (EO) in privatization in Sudan had very limited success. Yet, he found that the majority of the trade unionists and employees have positive attitudes to $\mathrm{EO}$ in privatization. $\mathrm{He}$ provided evidence that EO in privatization is a good thing since EO enhances productivity and leads to more employee loyalty to the enterprise. Musa concluded that government should encourage employees to buy shares in their companies.

Awamleh (2002) used a questionnaire survey to examine public officials' attitudes in a sample of 24 public enterprises in Jordan. He found that respondents believe that some forms of privatization such as joint-venture and contracting are more appropriate for Jordan than other forms such as transfer of management and ownership to private sector. Awamleh concluded that social orientation, improved economic climate, administrative development, and political support are of great importance in easing privatization in Jordan. Al-Adaileh (2004) 
examined the employees' attitudes concerning administrative, economic and social dimensions in Arab Potash and Jordan Phosphate Companies. He found positive attitude towards the administrative and economic dimensions and neutral attitude towards the social dimension. He also found a significant relationship between educational factor and employees' attitudes towards privatization. Ram (2012) found that most of the employees are satisfied with their jobs after privatization, as compared to the situation when it was a public sector organization. Ram noticed that many employees are willing to leave the security of government employment for the more risky but financially rewarding private sector employment. In contrast, Jresat (2012) found that there is neutral impact to the privatization process on the employees' performance in a cement Company.

Shun (2005) examined attitudes of housing professionals at three different occupational levels: top, middle and frontline managers toward privatization in Hong Kong. He found that top managers held the firmest beliefs under the privatization followed by the middle managers. Frontline managers are unlikely to hold firm beliefs. Shun also observed that there are no remarkable differences among the housing professionals based on their characteristics.

Carrera et al. (2005) found that educated respondents in bad economic condition seem to suffer the consequences of privatization more than people in other economic condition. They claimed that privatization has a redistributive impact against the low middle classes. Carrera et al. suggested that delaying the privatization of public utilities, especially where the deprivation of the educated middle classes, makes the perception of the consequences of privatization more acute.

Wated et al. (2008) used semi- structured interviews among Ecuadorian employees to clarify mixed beliefs associated with privatization. They stressed the importance of assessing beliefs associated with privatization when implementing privatization programs and highlighted the distinct role played by positive and negative beliefs. Wated et al. provide evidence that the positive beliefs concern the economic and organizational benefits of privatization while the negative beliefs concern its social and national costs.

Yonnedi (2009) examined the relationship between privatization of State-Owned Enterprises (SOE's), organizational change and performance. He provided evidence to suggest that privatization brought about important alignments among the organization's goals and its competitive environment. He also found that privatization process altered behavior, incentives and performance of formerly SOE's. Yonnedi confirmed the importance of leadership in the privatization and the need for managerial training programs targeting the managers of newly privatized firms.

Sarmah (2013) examined attitude of University students towards privatization of higher education in India. Students have shown positive attitudes towards the privatization of higher education. Similarly, Kousadikar and Singh (2013) demonstrated that privatization enhances the efficiency and profit generation of the state owned enterprises. They observed that sectors that showed tremendous success after privatization are insurance, banking, civil aviation, telecom and power.

As far as the GCC region is concerned, few studies have been conducted to examine employees attitudes toward privatization (see for example, Saudi Arabia: Mahmoud, 1992; Al-Modaf, 2003; Al-Homeadan, 2004; Al-Ghamdi et al., 2004; Alzahrani, 2011; Qatar: Al-Faori and Jolo, 1998; Kuwait: Madzikanda \& Ezinne, 2008; Oman: Ram \& Prabhakar, 2011). A brief review of these studies is offered in the following section.

Mahmoud (1992) made the point that poor performance of public enterprises is a function of factors such conflicting goals, government intervention, lack of competition and ineffective accountability. He believes that a successful privatization program requires public support, managerial ability and support, legislative actions, selection and preparation of enterprises and adequate capital markets. Al-Modaf (2003) found that students have positive attitudes toward anticipated changes in promotion criteria, as well as the salary and hiring systems. He also found that respondents have negative attitudes toward anticipated changes in the work time, workload, firing system, and levels of job security. Al-Modaf recommended that the government should take responsibility for those who lose their jobs due to privatization by training them or reemploying them in other places in the public sector. Al-Homeadan (2004) found that the department heads in the public sector do hold favorable attitudes towards privatization and they are satisfied with privatization and practices that it brings with it. Al-Ghamdi et al. (2004) showed that employees have positive attitudes toward privatization. They observed that employees appear to be ready and prepared to accept the privatization of their company. Al-Ghamdi et al. recommended that the process of privatization of Saudia be initiated gradually and employees be allowed to take part in the process of privatization of their company by granting them free stocks in the company. Alzahrani (2011) reported a strong positive impact of privatization in the performance level of employees of Electricity Company in Riyadh Saudi Arabia. 
Al-Faori and Jolo (1998) examined the impact of privatization of the Qatari public corporation Q-Tel on employees. The researchers found positive attitudes regarding the privatization process. They concluded that privatization success requires government support and employees awareness.

Madzikanda and Ezinne (2008) used to survey interview to examine Kuwait employees' perception about the effect of privatization on employment system. They found that respondents' attitudes towards privatization were overwhelmingly negative. They also found that respondents' attitudes were largely influenced by their concerns on the perceived changes in the employment system, in particular job security. Madzikanda and Ezinne concluded that Kuwaitization and job security to be the most important variables that influence employees support for privatization.

Ram and Prabhakar (2011) examined the impact of privatization on job satisfaction of employees of a public sector telecom company in Oman. They found that most of the respondents are satisfied with their jobs after the privatization of Omantel, as compared to the situation when Omantel was owned by the public sector. Ram and Prabhakar observed that the level of job satisfaction is higher among the older and perhaps more experienced employees.

\section{Data Collection and Study Methodology}

\subsection{Data Collection}

A questionnaire comprises six sections was constructed and piloted by five university professors who have good experience in research and the area of study in order to enhance its validity. They made some useful observations that have been incorporated in the final version of the questionnaire before distribution. The first section of the questionnaire contained background information about the respondents. Sections 2 to 6 of the questionnaire asked the respondents, whether employees or managers, to what extent they agree or disagree with different aspects of privatization including forms of privatization, possible obstacles toward privatization, fields of privatization, privatization motives and factors facilitating privatization. The respondents were asked to provide their answers on 1-5 likert scale, where 1 denotes strongly disagree and 5 denotes strongly agree. During the period between June and August 2014, 400 copies of the questionnaire distributed to employees and managers in 21 companies privatized under Kuwait Investment Agency (KIA) (Note 1). Out of 400 distributed questionnaires, 238 returned completed resulting in $60 \%$ usable response rate.

Table 1. List of the privatized companies surveyed in the current study

\begin{tabular}{ll}
\hline No. & Company \\
\hline 1 & Commercial Facilities Co. \\
2 & Al-Ahli Bank of Kuwait \\
3 & United Reality Co. \\
4 & Market Complexes Co. \\
5 & AlAhli Insurance Co. \\
6 & National Real estate co. \\
8 & National Industries Co. \\
9 & Kuwait Insurance Co. \\
10 & Gulf Cable Co. \\
11 & Securities House \\
12 & Industrial investment Co. \\
13 & Gulf insurance co. \\
14 & Security Group \\
15 & Gulf Bank \\
16 & The public Warehousing \\
17 & Commercial Bank of Kuwait \\
19 & Contracting \& Marine Services \\
20 & Warba Insurance Co. \\
21 & Mobil tel. Co. \\
\hline
\end{tabular}

\subsection{Study Methodology}

To assess internal consistency of the completed questionnaires, Cronbach's Alpha coefficient of reliability was undertaken for the answers of employees, managers and the sample at large. They appeared to be $0.937,0.932$ 
and 0.938 respectively. This suggests that the items covered in the questionnaire have a relatively high internal consistency. A reliability coefficient of 0.80 or more is considered acceptable in social science research.

Descriptive statistics will be used to identify to what extent the respondents agree or disagree with different aspects of privatization. To identify whether employees and managers assign the same or different levels of agreement to different aspects of privatization, Kruskal- Wallis test will be performed.

\section{Results of the Analysis}

\subsection{Respondents' Background}

The first section of the questionnaire contained background information about the respondents including: gender, nationality, age, last academic qualifications, job position and years of experience. A summary of the respondents' background information is presented in table 2. It evident from the table that almost two third of the respondents' are males and $56 \%$ of them are Kuwaitis. The vast majority of the respondents (58\%) aged between 23- 35 years. Table 2 also revealed that around $70 \%$ of the respondents have university degrees. Furthermore, almost $80 \%$ of the respondents declared that they have more than 3 years of work experience. The range of differences in the respondents' background is expected to give credibility to the outcome of the analysis.

Table 2. Background information about the respondents

\begin{tabular}{|c|c|c|c|}
\hline & Frequency & Percent & Cumulative Percent \\
\hline \multicolumn{4}{|l|}{ Gender } \\
\hline Male & 153 & 64.3 & 66.3 \\
\hline Female & 85 & 35.7 & 100 \\
\hline \multicolumn{4}{|l|}{ Nationality } \\
\hline Kuwaiti & 133 & 55.9 & 59.3 \\
\hline Non-Kuwaiti & 105 & 44.1 & 100 \\
\hline \multicolumn{4}{|l|}{ Age } \\
\hline Less than 23 Years & 16 & 6.7 & 6.7 \\
\hline 23-35 Years & 137 & 57.6 & 64.3 \\
\hline 36- 50 Years & 67 & 28.2 & 92.5 \\
\hline More than 50 Years & 18 & 7.5 & 100 \\
\hline \multicolumn{4}{|l|}{ Last Academic Qualifications } \\
\hline Less than Secondary Certificate & 13 & 5.5 & 5.5 \\
\hline Secondary Certificate & 16 & 6.7 & 12.2 \\
\hline Diploma & 44 & 18.5 & 30.7 \\
\hline BA & 147 & 61.8 & 92.5 \\
\hline Masters & 17 & 7.1 & 99.6 \\
\hline $\mathrm{PhD}$ & 1 & 0.4 & 100 \\
\hline \multicolumn{4}{|l|}{ Job Position } \\
\hline Employee & 147 & 61.8 & 61.8 \\
\hline Manager & 91 & 38.2 & 100 \\
\hline \multicolumn{4}{|l|}{ Work Experience } \\
\hline Less than 3 years & 45 & 18.9 & 18.9 \\
\hline 3- 10 Years & 102 & 42.9 & 61.8 \\
\hline 11-15 Years & 42 & 17.6 & 79.4 \\
\hline More than 15 Years & 49 & 20.6 & 100 \\
\hline
\end{tabular}

\subsection{Forms of Privatization}

A number of privatization forms adopted by different countries in the world and expected to be undertaken by the public sector in Kuwait were included in the questionnaire and the respondents were asked whether they agree or disagree that these forms be adopted in Kuwait. The results of their answers are summarized in table 3. 
Table 3. Respondents extent of agreement with the forms of privatization

\begin{tabular}{|c|c|c|c|c|c|c|}
\hline & Mean & Median & Std. Deviation & Minimum & Maximum & Rank \\
\hline Deregulation & 3.68 & 4.00 & 1.20 & 1.00 & 5.00 & 1 \\
\hline Partial Sale & 3.36 & 3.00 & 1.24 & 1.00 & 5.00 & 6 \\
\hline Full Sale & 3.01 & 3.00 & 1.40 & 1.00 & 5.00 & 8 \\
\hline Long-Term Lease & 3.29 & 3.00 & 1.26 & 1.00 & 5.00 & 7 \\
\hline Joint Venture Partnership & 3.64 & 4.00 & 1.16 & 1.00 & 5.00 & 3 \\
\hline Employee Stock Ownership & 3.55 & 4.00 & 1.18 & 1.00 & 5.00 & 5 \\
\hline Franchising & 3.60 & 4.00 & 1.19 & 1.00 & 5.00 & 4 \\
\hline Outsourcing & 3.68 & 4.00 & 1.24 & 1.00 & 5.00 & 1 \\
\hline
\end{tabular}

It can be observed in table 3 that the respondents expressed relatively high levels of agreement with all forms of privatizations contained in the questionnaire as mirrored by the mean and the median of each of these forms. The relatively low standard deviations appeared in the table indicate that there were low variations in the extent of agreement with each form of privatization. While the table disclosed that the respondents who took part in the survey conveyed high levels of agreement with the adoption of privatization forms such deregulation, outsourcing and joint ventures partnerships, the respondents were in less agreement with adopting privatization forms such as full or sale, partial sale and long- term lease as reflected by the rank appeared in the last column of table 3 (Note 2).

Kruskal Wallis Coefficients reported in table 4 showed consistency in the respondents levels of agreement with all forms of privatization except for the franchising form. This might due to the fact that franchising is not a popular form of privatization in Kuwait. Franchising in the Arab Gulf region is mainly associated with international brand names.

Table 4. Kruskal Wallis test of forms of privatization

\begin{tabular}{lll}
\hline & Chi-Square & Sig. \\
\hline Deregulation & 1.07 & 0.30 \\
Partial Sale & 0.85 & 0.36 \\
Full Sale & 0.26 & 0.61 \\
Long-Term Lease & 0.52 & 0.47 \\
Joint Venture Partnership & 0.09 & 0.76 \\
Employee Stock Ownership & 0.24 & 0.63 \\
Franchising & 5.75 & 0.02 \\
Outsourcing & 2.15 & 0.14 \\
\hline
\end{tabular}

This result of the analysis reflects the nature of the Kuwaiti economy and Kuwaiti employees. Kuwait is oilexporting country and classified as one of the richest countries in the World. According to the World Development Indicators (WBI) database accessed on 25 August 2014, Kuwait was ranked 11 in a list of 189 countries with US $\$ 56,367$ per capita income in 2013 . Given that $75 \%$ of the Kuwaiti national labor force is employed by the public sector, this implies that public sectors employees earn high salaries. Kuwaiti employees are then having little incentive in any privatization program. Hence, they prefer the light forms of privatization where the public sector continues to exercise a certain degree of ownership and control through outsourcing, deregulation and joint venture partnership forms of privatization. This reality is also reflected by the relatively low levels of the respondents agreement with forms of privatization such partial sale, full sale and long- term lease. Thus, full-fledged privatization that takes away from the public sector any sort of ownership and control will deprive Kuwaiti nationals from privileges they enjoy from working for the public sector.

\subsection{Obstacles to Privatization}

A list of potential obstacles to privatization advanced in the literature were included in the questionnaire and the respondents were asked to state to what extent they agree or disagree with each of them. The results of their statement are summarized in table 5. 
Table 5. The extent of respondents' agreement with obstacles to privatization

\begin{tabular}{|c|c|c|c|c|c|c|}
\hline & Mean & Median & Std. Deviation & Minimum & Maximum & Rank \\
\hline The fear of extensive government regulation & 3.55 & 4.00 & 1.27 & 1.00 & 5.00 & 3 \\
\hline $\begin{array}{l}\text { Difficulty to obtain the interest of both owners and } \\
\text { employees }\end{array}$ & 3.53 & 3.00 & 1.18 & 1.00 & 5.00 & 5 \\
\hline $\begin{array}{l}\text { Problems sometimes arise in various aspects of the } \\
\text { privatization process (bidding, contract } \\
\text { specification, monitoring and enforcement) }\end{array}$ & 3.46 & 3.00 & 1.13 & 1.00 & 5.00 & 7 \\
\hline $\begin{array}{l}\text { Private organizations will face difficulty to find } \\
\text { sources of fund necessary to finance privatization }\end{array}$ & 3.25 & 3.00 & 1.28 & 1.00 & 5.00 & 9 \\
\hline $\begin{array}{l}\text { Some projects entails social responsibility that can } \\
\text { only be maintained by the public sector }\end{array}$ & 3.58 & 4.00 & 1.19 & 1.00 & 5.00 & 2 \\
\hline Opposition from employees & 3.19 & 3.00 & 1.37 & 1.00 & 5.00 & 10 \\
\hline $\begin{array}{l}\text { Absence of competition and profit incentives in the } \\
\text { public sector }\end{array}$ & 3.63 & 4.00 & 1.25 & 1.00 & 5.00 & 1 \\
\hline Absent of a strong capital market & 3.40 & 3.00 & 2.34 & 1.00 & 3.00 & 8 \\
\hline
\end{tabular}

It can be deduced from table 5 that the respondents showed high degree of agreement with almost all possible obstacles to privatization listed in the questionnaire as reflected by the reported means and medians. The highest degree of agreement was associated with obstacles such as absence of competition and profit incentives in the public sector, some projects entails social responsibility that can only be maintained by the public sector, privatization results in layoffs of public sector's employees and fear of extensive government regulation. On the other hand, potential obstacles like opposition from employees, private organizations will face difficulty to find sources of fund necessary to finance privatization and absent of a strong capital market received the lowest degree of the respondents' agreement.

The undertaken Kruskal Wallis test to identify possible differences between employees and management degree of agreement with obstacles to privatization reported in table 6 pointed to several significant differences. Differences in the extent of agreement appeared about obstacles such as opposition from employees, absence of competition and profit incentives in the public sector and absent of a strong capital market.

Table 6. Kruskal Wallis test of obstacles to privatization

\begin{tabular}{lcc}
\hline & Chi-Square & Sig. \\
\hline The fear of extensive government regulation & 3.41 & 0.07 \\
Difficulty to obtain the interest of both owners and employees & 0.27 & 0.60 \\
Problems sometimes arise in various aspects of the privatization process(bidding, contract & 0.32 & 0.57 \\
specification, monitoring and enforcement) & 0.93 & 0.34 \\
Private organizations will find difficult to find sources of fund necessary to finance privatization & 0.75 & 0.39 \\
Some projects entails social responsibility that can only be maintained by the public sector & 3.92 & 0.05 \\
Opposition from employees & 0.04 & 0.84 \\
Private firms may pay low wages and fringe benefits & 2.87 & 0.09 \\
Privatization results in layoffs of public sector's employees & 4.17 & 4.13 \\
Absence of competition and profit incentives in the public sector & 0.04 & 0.04 \\
Absent of a strong capital market & &
\end{tabular}

The result of the analysis is not surprising. In a rich country with high annual revenues from oil and small population like Kuwait, public sectors enterprises are not driven by profit. In their current form, they do not look attractive for private investors. Another potential obstacle for privatization in Kuwait is the fear of employees' layoff. This is also predictable since most of the state enterprises in Kuwait suffer from invisible unemployment. Any privatization program will results in massive redundancy. The fact that Kuwaiti employees have generous salaries and other benefits and Kuwait has a small market will make it difficult to find replacement jobs to laid-off employees. This would provoke some serious social problems. 
The respondents further showed that the fear of extensive government regulation is another obstacle towards privatization in Kuwait. Once again, this result is predictable since Kuwait is viewed as being highly bureaucratic country. In this respect, United Kingdom government stated in Trade and Investment: Doing Business in Kuwait "Highly bureaucratic application procedures hinders the Kuwait business climate" (Note 3). Foreign companies still report numerous delays in attaining approval to operate in Kuwait and FDI law of 2003 has yet to improve investment climate sufficiently.

\subsection{Fields of Privatization}

The third section of the questionnaire contained a number of different fields of privatization and the respondents were asked to spell out to what extent they agree with each of the fields. The results of their responses are condensed table 7 .

Table 7. Respondents extent of agreement with fields of privatization

\begin{tabular}{lllllll}
\hline & Mean & Median & Std. Deviation & Minimum & Maximum & Rank \\
\hline Luxury goods and services & 3.69 & 4.00 & 1.45 & 1.00 & 5.00 & 3 \\
Light and moderate industries & 3.76 & 4.00 & 1.33 & 1.00 & 5.00 & 1 \\
Food and agricultural products & 3.32 & 3.00 & 1.45 & 1.00 & 5.00 & 7 \\
Strategic and heavy industries & 3.43 & 4.00 & 1.47 & 1.00 & 5.00 & 5 \\
Health & 3.21 & 3.00 & 1.55 & 1.00 & 5.00 & 8 \\
Education & 3.42 & 3.50 & 1.48 & 1.00 & 5.00 & 6 \\
Transportation & 3.50 & 4.00 & 1.45 & 1.00 & 5.00 & 4 \\
Communications & 3.74 & 4.00 & 1.48 & 1.00 & 5.00 & 2 \\
Water & 2.97 & 3.00 & 1.59 & 1.00 & 5.00 & 10 \\
Electricity & 3.03 & 3.00 & 1.58 & 1.00 & 5.00 & 9 \\
\hline
\end{tabular}

Although the respondents appeared to agree that most of the fields mentioned in the questionnaire can be subject to privatization, they expressed stronger agreement with projects in light and moderate industry, communication and luxury goods and services. These fields achieved the highest means and medians. However, the respondents were not enthusiastic about privatizing projects in strategic sectors such as water, electricity, health and food and agriculture products.

To identify differences between the extent of agreement that the surveyed employees and managers show to the fields of privatization covered in the questionnaire, the Kruskal Wallis coefficient was undertaken and reported in table 8 .

Table 8. Kruskal Wallis test of fields of privatization

\begin{tabular}{lll}
\hline & Chi-Square & Sig. \\
\hline Luxury goods and services & 0.44 & 0.51 \\
Light and moderate industries & 0.62 & 0.43 \\
Food and agricultural products & 0.52 & 0.47 \\
Strategic and heavy industries & 1.00 & 0.96 \\
Health & 0.02 & 0.89 \\
Education & 1.00 & 0.96 \\
Transportation & 0.03 & 0.86 \\
Communications & 2.98 & 0.08 \\
Water & 1.00 & 0.98 \\
Electricity & 0.13 & 0.72 \\
\hline
\end{tabular}

It can be observed from the table that there is insignificant difference between respondents about any of the privatization fields. This implies the respondents, whether employees or managers, have the same level of agreement about the fields that will be subject to privatization.

The result of the analysis is predictable since water, electricity, health and food are strategic sectors and they receive massive state subsidies. Privatizing these sectors means withdrawing government support to these sectors. This will hit hard the pockets of employees as well as managers pockets. Hence, consensus among employees 
and managers is fully understandable. Similarly, sectors like communications and luxury goods and services are not subsidized by the government. Hence, it is for this reason that the respondents strongly agreed to privatize projects within these sectors.

\subsection{Privatization Motives}

The questionnaire contained a number of possible motives for privatization appeared in previous research and the respondents were asked to indicate to what extent they agree or disagree with each of them. The results of their answers are reported in table 9.

Table 9. Respondents extent of agreement with motives of privatization

\begin{tabular}{|c|c|c|c|c|c|c|}
\hline & Mean & Median & Std. Deviation & Minimum & Maximum & Rank \\
\hline Motivating regional economic openness & 3.77 & 4.00 & 1.36 & 1.00 & 5.00 & 10 \\
\hline Motivating international economic openness & 3.44 & 4.00 & 1.62 & 1.00 & 5.00 & 17 \\
\hline Stimulating worldwide political orientation & 3.41 & 3.00 & 1.31 & 1.00 & 5.00 & 18 \\
\hline Fostering economic growth & 3.97 & 4.00 & 1.36 & 1.00 & 5.00 & 5 \\
\hline Achieving high microeconomic efficiency & 3.84 & 4.00 & 1.45 & 1.00 & 5.00 & 8 \\
\hline Achieving high profitability & 3.60 & 4.00 & 1.68 & 1.00 & 5.00 & 14 \\
\hline Achieving high allocative efficiency & 3.79 & 4.00 & 1.34 & 1.00 & 5.00 & 9 \\
\hline Achieving high productive efficiency & 3.52 & 4.00 & 1.66 & 1.00 & 5.00 & 16 \\
\hline Reducing unnecessary subsidies & 3.37 & 3.00 & 1.42 & 1.00 & 5.00 & 19 \\
\hline $\begin{array}{l}\text { Strengthening the role of the private sector in the } \\
\text { economy }\end{array}$ & 4.00 & 4.00 & 1.31 & 1.00 & 5.00 & 4 \\
\hline Improving the public sector's financial health & 3.92 & 4.00 & 1.37 & 1.00 & 5.00 & 7 \\
\hline $\begin{array}{l}\text { Enhancing optimal allocation of the public sector's } \\
\text { resources }\end{array}$ & 3.70 & 4.00 & 1.44 & 1.00 & 5.00 & 12 \\
\hline Minimizing political interference & 3.75 & 4.00 & 1.44 & 1.00 & 5.00 & 11 \\
\hline Increasing competition & 3.97 & 4.00 & 1.36 & 1.00 & 5.00 & 5 \\
\hline Improving investment climate in Kuwait. & 4.09 & 5.00 & 1.31 & 1.00 & 5.00 & 3 \\
\hline Developing foreign economic relations with Kuwait & 4.10 & 5.00 & 1.24 & 1.00 & 5.00 & 2 \\
\hline $\begin{array}{l}\text { Improving quality of goods and services in the Kuwaiti } \\
\text { economy }\end{array}$ & 4.13 & 5.00 & 1.29 & 1.00 & 5.00 & 1 \\
\hline Rationing of spending and consumption & 3.62 & 4.00 & 1.30 & 1.00 & 5.00 & 13 \\
\hline Curbing inflation & 3.60 & 4.00 & 1.39 & 1.00 & 5.00 & 14 \\
\hline
\end{tabular}

According to table 9, the respondents agreed that all the listed factors in the questionnaire can be potential motives for privatization. However, the respondents agreed more with privatization motives such improving quality of goods and services in the Kuwaiti economy, developing foreign economic relations, improving investment climate, strengthening the role of the private sector in the economy, increasing competition and fostering economic growth in Kuwait. The respondents conveyed lower levels of agreement to motives such as: reducing unnecessary subsidies, stimulating worldwide political orientation, motivating international economic openness and achieving high productive efficiency as reflected by their means and medians.

Kruskal Wallis test reported in table 10 reflects consensus among the respondents about the extent of their agreement about all possible privatization motives except for strengthening the role of the private sector in the economy, achieve high profitability and increasing competition.

Table 10. Kruskal Wallis test of motives of privatization

\begin{tabular}{lll}
\hline & Chi-Square & Sig. \\
\hline Regional economic openness & 0.43 & 0.51 \\
International economic openness & 0.14 & 0.71 \\
Worldwide political orientation & 2.08 & 0.15 \\
Foster economic growth & 2.55 & 0.11 \\
\hline Achieve high microeconomic efficiency & 2.63 & 0.11 \\
Achieve high profitability & 8.14 & 1.00 \\
Achieve high allocative efficiency & 0.26 & 0.61 \\
\hline
\end{tabular}




\begin{tabular}{lll}
\hline Achieve high productive efficiency & 3.09 & 0.08 \\
Reduce unnecessary subsidies & 0.37 & 0.55 \\
Strengthening the role of the private sector in the economy & 10.37 & 1.00 \\
Improving the public sector's financial health & 0.21 & 0.65 \\
Enhancing optimal allocation of the public sector's resources & 0.60 & 0.44 \\
Minimizing political interference & 1.25 & 0.26 \\
Increasing competition & 4.21 & 0.04 \\
Improving investment climate in Kuwait. & 1.57 & 0.21 \\
Developing foreign economic relations with Kuwait & 0.43 & 0.51 \\
Improving quality of goods and services in the Kuwaiti economy & 0.63 & 0.43 \\
Rationing of spending and consumption & 1.00 & 0.99 \\
Curbing inflation & 0.82 & 0.37 \\
\hline
\end{tabular}

The results of the respondents' answers revealed that effective privatization program would strengthen the role of the private sector in the Kuwaiti economy, improve the quality of goods and service and increase competition. This is expected to improve investment climate in Kuwait, develop foreign economic relations with Kuwait and foster economic growth. The respondents do not seem to strongly agree that privatization would reduce unnecessary subsidies, stimulate worldwide political orientation and motivate worldwide economic openness. This implies that the government will continue to maintain some sort of subsidies even after privatization. Kuwait's nature of privatized businesses combined with the small size of the Kuwaiti market would make limited impact on the international arena. In other words, privatization program in Kuwait will have limited effect on stimulating worldwide political orientation and in motivating worldwide economic openness.

\subsection{Factors Facilitating Privatization}

The questionnaire contained a number of factors that helps in facilitating privatization. The respondents were asked to state to what extent they agree or disagree with each of these factors. The outcome of their answers is presented in table 11 .

Table 11. Respondents extent of agreement with factors facilitating privatization

\begin{tabular}{|c|c|c|c|c|c|c|}
\hline & Mean & Median & Std. Deviation & Minimum & Maximum & Rank \\
\hline Social orientation of the advantages of privatization & 3.89 & 4.00 & 1.32 & 1.00 & 5.00 & 5 \\
\hline Political leadership support & 3.90 & 4.00 & 1.31 & 1.00 & 4.00 & 4 \\
\hline $\begin{array}{l}\text { Creating an improved economic climate for } \\
\text { privatization }\end{array}$ & 3.87 & 4.00 & 1.35 & 100 & 5.00 & 6 \\
\hline Comprehensive administrative development & 3.94 & 4.00 & 1.35 & 1.00 & 5.00 & 2 \\
\hline Simplifying government regulation & 3.94 & 4.00 & 1.37 & 1.00 & 5.00 & 2 \\
\hline Obtaining interest of both owners and employees & 3.95 & 4.00 & 1.33 & 1.00 & 5.00 & 1 \\
\hline $\begin{array}{l}\text { Agreeing on various aspects of the privatization } \\
\text { process (bidding, contract specification, monitoring } \\
\text { and enforcement) }\end{array}$ & 3.84 & 4.00 & 1.29 & 1.00 & 5.00 & 7 \\
\hline
\end{tabular}

Table 11 demonstrates that the respondents agreed with all factors listed in the questionnaire as mirrored by the means and medians. What draws attention in the table is that the means of all factors are very close. They ranged between 3.84 and 3.95. However, the strongest degrees of agreement were about factors such as: obtaining interest of both owners and employees, simplifying government regulation, comprehensive administrative development and political leadership support.

Kruskal Wallis test reported in table 12 showed consensus among respondents about all factors listed in the questionnaire as reflected by the resulted Chi- squares and their levels of significance. 
Table 12. Kruskal Wallis test of factors facilitating privatization

\begin{tabular}{|c|c|c|}
\hline & Chi-Square & Sig. \\
\hline Social orientation of the advantages of privatization & 0.48 & 0.49 \\
\hline Political leadership support & 1.73 & 0.19 \\
\hline Creating an improved economic climate for privatization & 0.86 & 0.36 \\
\hline Comprehensive administrative development & 2.00 & 0.16 \\
\hline Simplifying government regulation & 0.57 & 0.45 \\
\hline Obtaining interest of both owners and employees & 0.05 & 0.82 \\
\hline $\begin{array}{l}\text { Agreeing on various aspects of the privatization process (bidding, contract specification, monitoring and } \\
\text { enforcement) }\end{array}$ & 1.83 & 0.18 \\
\hline
\end{tabular}

The respondents seem to agree that different steps need to be undertaken to facilitate privatization in Kuwait. Before adopting any privatization program, the government must first convince future owners and current employees, of potentially privatized projects, of the importance of privatization. The government should also adopt simple regulation and undergo comprehensive administrative development to ensure effective privation program.

\section{Conclusion}

Adopting privatization programs in countries with minimal states involvement and state subsidies is easier than adopting them in countries with heavy state involvement and state subsidies. Kuwait is a country with small population and large income from oil exports. To ensure fair wealth distribution, the State is responsible for securing jobs for all its citizens at high salaries. It also provides free health care and education from the elementary stage up to the university levels. The state further heavily subsidizes water, electricity, fuel and many of the basic goods and services. Within this environment, privatizing any of the State's enterprises will result in laying off employees, reducing or even abolishing subsidies, change in employees' income and other jobs allowances and this would result in an increase in prices of goods and services. An additional dimension needs to be added when carrying out any privatization program in Kuwait is that Kuwait has a freely elected parliament. Any privatization program must be approved by the parliament. Carrying out privatization program against this background is not straight forward. It was, therefore, of paramount importance to conduct this study that aims at assessing different aspects of privatization in Kuwait to assist policy makers as well other similar regional countries in formulating their future privatization programs. During the period between June and August 2014, 400 questionnaires distributed to employees and managers of 21 privatized companies. 238 questionnaires completed resulting in $60 \%$ usable rate and used as basis for this study. The questionnaire covered different aspects of privatization including: its forms, obstacles, motives, factors facilitating it and its fields. The respondents were asked to express to what extent they agree or disagree with various aspects of privatization using 5 likert scale ranging from strongly disagree to strongly agree. The respondents were divided between Kuwaitis and non- Kuwaiti and represented both genders with different ages and academic qualifications. Most of the respondents also had several years of work experience. Variations in the respondent background provided strong basis for the analysis and the outcome of the study.

The results of the analysis revealed that the respondents prefer outsourcing, deregulation and joint venture partnerships forms of privatization. The respondents still want the State to continue to have a specific role even after privatization. This is not surprising since the government have the required resources and gives Kuwaiti assurance that privatization will not affect their standard of living they are accustomed to over the years. The respondents also demonstrated that privatization programs in Kuwait might confront difficulties due to the absence of competition and profit incentives in the public sector. They also demonstrated that privatization might face difficulty since some projects entails social responsibility that can only be maintained by the public sector and privatization results in layoffs of public sector's employees. They further fear that extensive government regulation and difficulty in obtaining the interest of both owners and employees would hinder privatization in Kuwait. To minimize obstacles towards privatization in Kuwait, state enterprises need to be administered and run in a competitive manner to enhance their profitability. The State should avoid excessive regulation to ensure smooth implantation of privatization. Education about the importance of privatization to the Kuwait economy and for the future generation would help in obtaining employees and owners' interest in privatization. Government should develop economic and social programs to deal with possible layoff as a result of privatization and it should continue to run enterprises entail social responsibility that cannot be maintained by the private sector. The respondents also emphasized that privatization should be restricted to light and moderate industries, transportation 
and light and moderate industries. On other hand, the respondents did not agree that privatization should include water, electricity, health, food and agricultural products. This result is expected since all these services and goods are either free of charge or heavily subsidized by the State.

Despite obstacles towards privatization, the respondents believe that an effective privatization program would result in improving quality of goods and services in the Kuwaiti economy, developing foreign economic relations, improving investment climate in Kuwait, strengthening the role of the private sector in the economy and fostering economic growth. They also believe that this can be achieved by obtaining interest of both owners and employees, undergoing comprehensive administrative development and political support from the leadership.

\section{Acknowledgement}

The authors acknowledge financial support and encouragement received by Arab Open University (AOU)-Kuwait branch throughout the execution of the project. However, the opinions expressed in this article are those of the authors, and they do not reflect in any way those of the institutions to which they are affiliated.

\section{References}

Akram, T. (1999). Privatization of public enterprises in Bangladesh: Problems and prospects. Social Science Research Network Electronic. Retrieved from http://papers.ssrn.com/sol3/papers.cfm?abstract_id=272605

Al-Adaileh, A. (2004). Jordanian employees' attitudes toward privatization: An empirical study on Arab Potash and Jordan Phosphate Companies. Administrative Sciences, Dirasat Journal, 31(1), 43-62.

Al-Faori, R., \& Jolo, H. (1998). Privatisation of the Qatari public corporation for tele-communication (Q-Tel) and its effects. Public Administration, 37(4), 713-747.

Al-Ghamdi, M., Al-Ghamdi, S., \& Al-Raddadi, M. (2004). An empirical study of the attitudes of Saudi Arabian Airlines employees toward privatization. Retrieved from http://faculty.kfupm.edu.sa/COE/sadiq/proceedings/SCAC2004/21.ASC046.EN.AlGhamdi.An\%20Empiric al\%20Study\%20of\%20the\%20Attitude\%20_1_.pdf

Al-Homeadan, A. (2004). Privatisation in Saudi Arabia: Is it time to introduction into the public sector domain? Journal of American Academy of Business, 4(1/2), 109-117.

Al-Modaf, O. (2003). Attitudes toward the effects of privatization on the employment system: A study of undergraduate college students in Saudi Arabia. Unpublished Ph.D. thesis, Virginia Polytechnic Institute and State University.

Al-Qudah, A. (2011). The operating efficiency and market value of Jordanian privatized firms: fixed and random effects analysis. Interdisciplinary Journal of Research in Business, 1(7), 99-116.

ALzahrani, A. (2011). The impact of privatization of the electricity company of Riyadh in Saudi Arabia at the employee's performance level. Retrieved from http://e-thesis.mutah.edu.jo/index.php/faculty-of-business-administration/53-department-of-public-administ ration/459-2012-05-02-10-43-47.pdf

Awamleh, N. (2002). Public officials' attitudes towards privatization in Jordan: A field survey. International Journal of Public Sector Management, 15(3), 237-256. http://dx.doi.org/10.1108/09513550210423389

Carrera, J., Checchi, D., \& Florio, M. (2005). Privatization discontent and its determinants: Evidence from Latin America. Retrieved from http://www.iadb.org/res/publications/pubfiles/pubS-500.pdf

Dong, X., Bowles, P., \& Ho, S. (2002). Share ownership and employee attitudes: Some evidence from China's post-privatization rural industry. Journal of Comparative Economics, 30, 812-835. http://dx.doi.org/10.1006/jcec.2002.1801

Durant, R., \& Legge, J. (2002). Politics, public opinion, and privatization in France: Assessing the calculus of consent for market reforms. Public Administration Review, 62(3), 307-223. http://dx.doi.org/10.1111/1540-6210.00181

Eiser, J., Reicher, S., \& Podpadec, T. (1996). Attitudes to privatization of UK public utilities: Anticipating industrial practice and environmental effects. Journal of Consumer Policy, 19(2), 193-208. http://dx.doi.org/10.1007/BF00412473

Ertuna, O. (1998). Constraints of privatization: the Turkish Case. Retrieved from http://www.nioclibrary.net/privatization/e035.pdf

Goic, S. (1999). Employees' attitudes towards employee ownership and financial participation in Croatia: 
Experience and cases. Journal of Business Ethics, 21(2/3), 145-155. http://dx.doi.org/10.1023/A:1006288808755

Helwege, J., \& Liang, N. (2004). Initial public offerings in hot and cold markets. Journal of Financial and Quantitative Analysis, 39, 541-569. http://dx.doi.org/10.1017/S0022109000004026

Islam, M., \& Farazmand, A. (2008). Perceptions of civil servants toward privatization and development: A new exploratory study. Humanities, Social Sciences and Law Public Organization Review, 8(1), 37-52. http://dx.doi.org/10.1007/s11115-008-0047-6

Jresat, S. (2012). The impact of privatization on the performance of the human resources in the Jordanian cement company in terms of employees' performance and the increase of the salaries and incentives. Interdisciplinary Journal of Contemporary Research in Business, 4(7), 353-366.

Keller, A., Dogan, C., \& Eroglu, O. (1994). Evaluating privatization policies in Turkey. International Journal of Public, 7(1), 15-24.

Khan, A. (1991). Is privatization in Pakistan purposeful? Retrieved from http://www.pide.org.pk/pdf/psde\%2018AGM/Is\%20Privitization\%20in\%20Pskitan\%20Purposeful.pdf

Kikeri, S., Nellis, J., \& Shirley, M. (1994). Privatization: lessons from market economies. World Bank Research Observer, 9, 241-272. http://dx.doi.org/10.1093/wbro/9.2.241

Kim, B., Kish, R., \& Vasconcellos, G. (2002). The Korean IPO market: Initial returns. Review of Pacific Basin Financial Markets \& Policies, 5, 219-253. http://dx.doi.org/10.1142/S0219091502000730

Kiymaz, H. (2000). The initial and aftermarket performance of IPOs in an emerging market: Evidence from Istanbul stock exchange. Journal of Multinational Financial Management, 10, $213-227$. http://dx.doi.org/10.1016/S1042-444X(99)00027-4

Kousadikar, A., \& Singh, T. (2013). Advantages and disadvantages of privatization in India. International Journal of Advanced System and Social Engineering Research, 3(1), 18-22.

lalkanthi, S., \& Mahaliyanaarachchi, R. (2001). Attitudes of the farmers and agricultural officers on privatisation- of agricultural extension service in up country vegetable sector in Sri Lanka. Tropical Agricultural Research, 13, 319-327.

Madzikanda, D., \& Ezinne, N. (2008). Employee attitude towards the privatization of Kuwait's government departments and state. International Public Management Review, 9(1), 107-129.

Mahmoud, M. (1992). Privatization: A solution to problems of public enterprises. Journal of King Abdul Aziz University, Economics and Administration, 5, 33-49. http://dx.doi.org/10.4197/Eco.5-1.2

Milman, C. (1996). Attitudes towards debt-equity-swaps and privatization of state-owned enterprises in Chile. Public Budgeting and Financial Management, 8(2), 170-187.

Momen, M. (2007). Implementation of privatization policy: Lessons from Bangladesh. The Innovation Journal: The Public Sector Innovation Journal, 12(2). Retrieved from http://www.innovation.cc/scholarly-style/momen privatization4e.pdf

Musa, K. (2002). Employee ownership in the privatization programme of Sudan progress, problems and prospects. Retrieved from http://unpan1.un.org/intradoc/groups/public/documents/cafrad/unpan009317.pdf

Nichols, T., Sugur, N., \& Kasapogil, A. (1998). Privatisation in Turkey: Employees' views on privatisation in the Turkish Cement Industry, and some comparisons with Britain. Work Employment \& Society, 12(1), 1-23. http://dx.doi.org/10.1177/0950017098121001

Public Authority for Civil Information. (2013). Statstical reports. Retrieved from http://www.paci.gov.kw

Ram, P. (2012). Post privatization job satisfaction among employees. International Journal of Academic Research in Business and Social Sciences, 2(1), 118-127.

Ram, P., \& Prabhakar, G. (2011). Privatizing monopolies in the Telecom Sector- Lessons from the employee job satisfaction perspective. International Journal of Humanities and Social Science, 1(6), 79-88.

Reid, M. (1994). Institutional preconditions of privatization in market-based political economies: Implications for Jordan. Public Administration and Development, 14(1), 65-77. http://dx.doi.org/10.1002/pad.4230140105

Sarmah, B. (2013). Attitude of university students, towards privatisation of higher education - A study. Indian 
Journal of Applied Research, 3(2), 81-83. http://dx.doi.org/10.15373/2249555X/FEB2013/28

Selvi, Y., \& Yilmaz, F. (2010). The importance of financial reporting during privatization: Turkish case. Retrieved from http://ideas.repec.org/a/alu/journl/v2y2010i12p20.html

Shahzad, U. (2005). Privatization in Bangladesh: The emergence of 'Family Capitalism'. Development and Change, 36(1), 157-182. http://dx.doi.org/10.1111/j.0012-155X.2005.00406.x

Shehadi, K. (2002). United Nations Development Programme: Lessons in privatization considerations for Arab States. Retrieved from http://www.mafhoum.com/press3/99E16.pdf

Shun, C. (2005). The impact of the privatization on the motivation of the housing professionals of the Hong Kong Housing Department. Unpublished master dissertation, the University of Hong Kong.

Struwig, F., \& Scheers, L. (2004). The effect of privatisation on front line employees in a service organisation. SAJEMS NS, 7(1), 1-21.

Tansel, A. (2001). The effects of privatization on labor in Turkey. Retrieved from http://ideas.repec.org/p/met/wpaper/0103.html

Taylor, D., \& Warrack, A. (1998). Privatization of state enterprise: policy drivers and lessons learned. International Journal of Public Sector Management, 11(7), 524-535. http://dx.doi.org/10.1108/09513559810247867

The World Bank. (2014). World Development Indicators. Retrieved from http://en.wikipedia.org/wiki/List_of_countries_by_GDP_(nominal)_per_capita

UK Trade and Investment. (2014). Doing Business in Kuwait, site visited on 30 August 2014. Retrieved from http://www.kuwait.doingbusinessguide.co.uk/the-guide/challenges/

Wated, G., Sanchez, J., \& Gomez, C. (2008). A two-factor assessment of the beliefs that influence attitudes toward privatization. Group and Organization Management, 33(1), 107-136. http://dx.doi.org/10.1177/1059601106291069

Yonnedi, E. (2009). Does privatization affect organizational change: A case of Indonesia. Paper presented at the $10^{\text {th }}$ Public Management Research Conference, Ohio State University, 1-3 October.

\section{Notes}

Note 1. List of the privatized companies covered in this study are included in table 1.

Note 2. The rank is based on the mean value of each form of privatization. The form that has the highest means is ranked No. 1, the second largest mean is 2 , and so on.

Note 3. UK Trade and Investment, Doing Business in Kuwait, site visited on 30 August 2014. http://www.kuwait.doingbusinessguide.co.uk/the-guide/challenges/

\section{Copyrights}

Copyright for this article is retained by the author(s), with first publication rights granted to the journal.

This is an open-access article distributed under the terms and conditions of the Creative Commons Attribution license (http://creativecommons.org/licenses/by/3.0/). 